\title{
VIRULENCE OF ISOLATED PSEUDOMONAS AERUGINOSA INFECTING DUCKLING AND ANTIBIOTIC RESISTANCE WITH AN EXPERIMENTAL TREATMENT TRIAL
}

\author{
MOSTAFA S. ABDOU ${ }^{1}$; ATEF A. SALIM ${ }^{2}$ AND EL DAKROURY, M.F. ${ }^{3}$ \\ ${ }^{1}$ Bacteriobiology Unit, Animal Health Research Institute, Provisional Lab Kafer El-Sheikh, \\ Agricultural Research Center (ARC), Egypt. \\ 2 Poultery Diseases Unit, Animal Health Research Institute, Provisional Lab Kafer El-Sheikh, \\ Agricultural Research Center (ARC), Egypt. \\ ${ }^{3}$ Pharmacology Dep., Faculty of Vet Medicine Matrouh Univ., Egypt
}

Received: 26 March 2021; Accepted: 27 April 2021

\begin{abstract}
The present study was conducted in Kafrelsheikh governorate to isolate P.aeruginosa from 120 ducks, sampling from cloacal swab, internal organs and tracheal swab of freshly dead, healthy and diseased ducklings at different ages which showed depression, emaciation, ocular and or nasal discharges, diarrhea and sometimes enlargement of hock joint and had lesions of airsacculitis, congested liver, catarrhal enteritis and sometimes presence of gelatinous material in the hock joints with rate of isolation of $16.66 \%$ (20 samples were positive). Serological identification of suspected isolates of $P$. aeruginosa showed that 16 isolates of polyvalent I group I and 4 isolates of polyvalent II group J. Susceptibility of the isolated $P$. aeruginosa for 11 antibiotics demonstrated that the highest resistance was noted against Erythromycin, Oxytetracycline, Ampicillin and Amoxicillin (95\%). The highest sensitivity of $P$. aeruginosa was observed against Florphenicol (80\%) and it used for treatment in experimental design and give good results. Multiplex PCR used to identify virulence represented by toxA gene, lasI gene and oprL gene of $P$. aeruginosa show that all isolates where positive for the 3 examined virulence genes and these indicate that all isolates were highly virulent strains and antibiotic resistance genes represented by qnrS gene, blaCTX gene and mexR gene of $P$. aeruginosa showed that all isolates where positive for the 3 examined $A B$ resistance exept isolate No 4 were negative for blaCTX and these indicate that all isolates were highly $\mathrm{AB}$ resistance exept isolate No 4 was not have blaCTX resistance gene. Experimental infection was done to study the Pathogenicity of $P$. aeruginosa which isolated from diseased ducklings on newly hatched ducklings with dose of infection of $0.2 \mathrm{ml}$ of $1 \times 10^{7} \mathrm{cfu} / \mathrm{ml} \mathrm{s} / \mathrm{c}$ and use the potent antibiotic florphenicol for treatment of experimentally infected ducks. Our study proved that virulence genes owned by the $P$. aeruginosa confirming its pathogenicity for ducks, especially in the presence of oprL gene which plays a great role in antimicrobial resistance, so biosafety was recommended for hatcheries and farms, the hygiene, cleaning and disinfection will reduce $P$. aeruginosa spreading in the farms.
\end{abstract}

Keyword: Pseudomonas aeruginosa, duckling, Virulence genes, antibiotic resistance genes, sensitivity test, Experimental infection.

Corresponding author: Mostafa S. Abdou

E-mail address: dr.mostafaabdou@yahoo.com

Present address: Bacteriobiology Unit, Animal Health Research Institute, Provisional Lab Kafer El-Sheikh, Agricultural Research Center (ARC), Egypt. 


\section{INTRODUCTION}

Pseudomonas aeruginosa an opportunistic pathogen, decrease host defenses causeing infection of yolk sac and omphalitis resulting in deaths of young ducks and hatched ducks. Mortality begins from hatching and continue for 10-14 days or more, and the infection with $P$. aeruginosa is responsible for mortality and clinical signs including respiratory signs and septicaemia (Bapat et al. 1985). P. aeruginosa can infect all tissues in poultry (Khattab et al., 2015). P. aeruginosa causes problems in ducks as septicemia, respiratory manifestation, lameness, conjunctivitis and diarrhea.

(Saif et al., 2008) Stated that the clinical signs include lameness; incoordination; swelling of head, and hock joint or footpads; diarrhea, and septicemia. (Barnes, 2003) mention that The affected ducks showed greenish watery diarrhea and paralytic signs with lameness in some birds and necropsy revealed echymotic and petechial haemorrhages on heart and liver, respectively (Qureshi, S.D. et al., 2010 and Hamza, M. Eid et al., 2019) isolated $P$. aeruginosa from trachea, heart, lung, liver and spleen of the affected ducks and it is gram-negative, aerobic gammaproteobacteria that can cause disease in animals and humans. $P$. aeruginosa is one of bacteria responsible for drug-resistant nosocomial infections. (Mena and Gerba, 2009).

$P$. aeruginosa is important in the etiology of many infectious diseases seen in humans (Silby et al., 2011). P. aeruginosa is one of the environmental associated diseases and serious diseases in poultry farms which has multifarious virulence genes and plays a major role in poultry outbreaks. P. aeruginosa produces cheesy deposits on air sacs, dyspnea and congestion of internal organs, pericarditis and peri-hepatitis (Kheir El din and Awaad 1986). The development of antibiotic resistance due to low permeability of outer membrane thus potentially compromises the effective therapeutic use of antimicrobial agents (Davies and Davies, 2010). Pseudomonas species demonstrated a high resistance to monotherapy of penicillins, tetracyclines, cephalosporins, fluoroquinolones, and macrolides. Only combination of drugs as Ticarcillin + Clavulanic acid, Cefoperazone + Sulbactum, Cefotaxime + Sulbactum, Piperacillin + Tazobactum, Ceftriaxome + Sulbactum according to (Javiya et al., 2008). Emergence and spread of resistance in bacteria may be due to mutational events introduced during bacteria replication and vertical transmission of genetic variants through generations in a particular bacteria strain. (Walker et al., 2002) Reported that $\mathrm{P}$. aeruginosa is non-spore forming rod, motile and gram-negative. This organism is resistant to many antimicrobials and can invade hatched ducks. Virulent strains of this bacterium can cause diarrhea, dehydration, dyspnea, septicemia, and death. $P$. aeruginosa produce hemolysis on blood agar due to activity of phospholipase $\mathrm{C}$ which is potent toxins can damage cells including red blood cells in vivo, resulting in hemorrhage, edema, and tissue necrosis.

$P$. aeruginosa has proteolytic enzymes degrade lipoproteins in the yolk, this permits its proliferation, enhance other bacteria to multiply (Garcia and Isenberg, 2007).

PCR is simple highly sensitive more rapid, than cell culture assay in detection of bacteria. So it could be recommended as screening method in laboratory (Schmidt et al., 1995) .

\section{MATERIALS AND METHODS}

I. Samples Collection according to (Middleton et al., 2005): A total of 120 samples were collected from diseased ducklings showing profuse diarrhea, respiratory manifestations, yellowish nasal secretion, ruffled feather and conjunctivitis 
and samples included liver, heart, yolk sac, cloacal swab and tracheal swabs were collected from many different farms in Kafrelsheikh governorate for isolation and identification of $P$. aeruginosa. All samples were handled and collected aseptically to prevent cross contamination using sterile sampling materials and transmitted immediately in ice box to be examined in the laboratory.

\section{Isolation and Biochemical} identification of p. aeruginosa:

Samples inoculated in nutrient broth and incubated at $37{ }^{\circ} \mathrm{C}$ for 24 hours, then sub cultured onto selective medium (MacConkey agar and Pseudomonas agar base) incubated at $37{ }^{\circ} \mathrm{C}$ for 24 hours and observe the non-lactose fermenting colonies and sub cultured onto tryptic soya agar plate to observe the pigmentation. Suspected colonies were picked up and subjected to further identifications based on colonial and cellular morphology, pigment production detection of fruity smell, oxidase test and Gram staining. Cultivation on laboratory media and all biochemical tests were performed according to (Quinn et al., 2002) and (Shukla and Mishra, 2015). Oxidase test, catalase test, arginine hydrolysis test, gelatin liquefaction, Indol, methyl red and urease test identified by API 20 typing system to confirm isolates (Cheesbrough, 2000).

\section{Serological identification:}

Serotyping of the isolated $P$. aeruginosa was applied by using slide agglutination technique (specific 4 polyvalent and 16 monovalent antisera) according to the recommendation of the manufacturer's protocol (Bio-Rad®, France) according to Glupczynski et al. (2010). The division of $P$. aeruginosa to groups based on $\mathrm{O}$ antisera of P.aeruginosa, depend on the International Antigen Typing Scheme (IATS) according to Legakis et al. (1982).

IV. Antibiotic Sensitivity Test: The antimicrobial sensitivity test was performed as reported by Finegold and Martin (1982) by disc diffusion method. Different antimicrobials were used such as En: Enrofloxacin $(5 \mu \mathrm{g})$, Nor: norfloxacin $(10$ $\mu \mathrm{g})$, Tl: tylosin $(15 \mu \mathrm{g})$, Fl: florphenicol

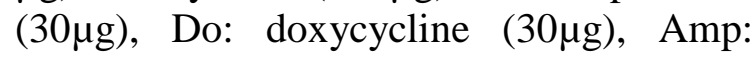
ampicillin $(10 \mu \mathrm{g})$, Aml: amoxicillin (10 $\mu \mathrm{g})$, CTX: cefotaxime $(30 \mu \mathrm{g})$, E: Erythromycin $(15 \mu \mathrm{g})$, CIP: Ciprofloxacin $(5 \mu \mathrm{g})$ and $\mathrm{T}$ : Oxytetracycline $(30 \mu \mathrm{g})$. The interpretation of the measured zone was done according to CLSI (2018).

\section{Multiplex PCR:}

1 - Extraction of DNA: samples was performed by QIAamp DNA Mini kit (Qiagen, Germany, $\mathrm{GmbH}$ ) with modifications from the manufacturer's recommendations, as in the kit. Oligonucleotide Primer. Primers were supplied from Metabion as in table (1).

2 - PCR amplification: For multiplex PCR.

3 - Analysis of the PCR Products: The products of PCR were separated by electrophoresis and the data analyzed through computer software, Primers sequences, target genes, amplicon sizes and cycling conditions for conventional PCR. 
Table 1: Target genes, amplicon sizes, primers sequences, and cycling conditions for conventional PCR.

\begin{tabular}{|c|c|c|c|c|c|c|c|c|}
\hline \multirow{2}{*}{$\begin{array}{c}\text { Target } \\
\text { gene }\end{array}$} & \multirow{2}{*}{$\begin{array}{c}\text { Primers } \\
\text { sequences }\end{array}$} & \multirow{2}{*}{$\begin{array}{c}\text { Amplified } \\
\text { segment } \\
\text { (bp) }\end{array}$} & \multirow{2}{*}{$\begin{array}{c}\text { Primary } \\
\text { denaturation }\end{array}$} & \multicolumn{3}{|c|}{ Amplification ( 35 cycles) } & \multirow{2}{*}{$\begin{array}{c}\text { Final } \\
\text { extension }\end{array}$} & \multirow[t]{2}{*}{ Reference } \\
\hline & & & & $\begin{array}{c}\text { Secondary } \\
\text { denaturation }\end{array}$ & Annealing & Extension & & \\
\hline \multirow[t]{7}{*}{ ToxA } & GACAACG & 396 & $94^{\circ} \mathrm{C}$ & $94^{\circ} \mathrm{C}$ & $55^{\circ} \mathrm{C}$ & $72^{\circ} \mathrm{C}$ & $72^{\circ} \mathrm{C}$ & Matar \\
\hline & CCCTCAG & & 5 min. & $30 \mathrm{sec}$. & $40 \mathrm{sec}$. & $45 \mathrm{sec}$. & $10 \mathrm{~min}$. & et al., 2002 \\
\hline & $\begin{array}{c}\text { CATCACC } \\
\text { AGC }\end{array}$ & & & & & & & \\
\hline & CGCTGGC & & & & & & & \\
\hline & CCATTCG & & & & & & & \\
\hline & CTCCAGC & & & & & & & \\
\hline & GCT & & & & & & & \\
\hline \multirow[t]{6}{*}{ LasI } & ATGATCG & 606 & & & & & & Bratu \\
\hline & TACAAATT & & & & & & & et al. 2006 \\
\hline & GGTCGGC & & & & & & & \\
\hline & GTCATGA & & & & & & & \\
\hline & AACCGCC & & & & & & & \\
\hline & AGTCG & & & & & & & \\
\hline \multirow[t]{8}{*}{ oprL } & ATG GAA & 504 & & & & & & Xu et al., \\
\hline & ATG CTG & & & & & & & 2004 \\
\hline & AAA TTC & & & & & & & \\
\hline & GGC & & & & & & & \\
\hline & CTT CTT & & & & & & & \\
\hline & CAG CTC & & & & & & & \\
\hline & GAC GCG & & & & & & & \\
\hline & ACG & & & & & & & \\
\hline \multirow[t]{6}{*}{ qnrS } & ACGACAT & 417 & $94^{\circ} \mathrm{C}$ & $94^{\circ} \mathrm{C}$ & $55^{\circ} \mathrm{C}$ & $72^{\circ} \mathrm{C}$ & $72^{\circ} \mathrm{C}$ & Robicsek \\
\hline & TCGTCAA & & $5 \mathrm{~min}$. & $30 \mathrm{sec}$. & $40 \mathrm{sec}$. & $45 \mathrm{sec}$. & $10 \mathrm{~min}$. & et al., 2006 \\
\hline & CTGCAA & & & & & & & \\
\hline & TAAATTG & & & & & & & \\
\hline & GCACCCT & & & & & & & \\
\hline & GTAGGC & & & & & & & \\
\hline \multirow[t]{10}{*}{ blaCTX } & ATG TGC & 593 & & & & & & Archambault \\
\hline & AGY ACC & & & & & & & et al., 2006 \\
\hline & AGT AAR & & & & & & & \\
\hline & GTK ATG & & & & & & & \\
\hline & GC & & & & & & & \\
\hline & TGG GTR & & & & & & & \\
\hline & AAR TAR & & & & & & & \\
\hline & GTS ACC & & & & & & & \\
\hline & AGA AYC & & & & & & & \\
\hline & AGC GG & & & & & & & \\
\hline \multirow[t]{6}{*}{$\operatorname{mexR}$} & GCGCCAT & 637 & & & & & & Sánchez \\
\hline & GGCCCAT & & & & & & & et al., 2002 \\
\hline & ATTCAG & & & & & & & \\
\hline & GGCATTC & & & & & & & \\
\hline & GCCAGTA & & & & & & & \\
\hline & AGCGG & & & & & & & \\
\hline
\end{tabular}




\section{Pathogenicity of $P$. aeruginosa:}

To study the Pathogenicity of $P$. aeruginosa isolates from diseased ducklings on newly hatched ducklings with dose of infection of $0.2 \mathrm{ml}$ of $1 \times 10^{7} \mathrm{cfu} / \mathrm{ml} \mathrm{s} / \mathrm{c}$.

\section{Experimental trials:}

It was carried out at Animal Health Research Institute, provisional lab in Kafr el-Sheikh governorate. seventy ducklings one day old were placed into isolation units, feed and water were provided ad libitum, 10 ducks were sacrificed and examined bacteriologically to be free from $P$. aeruginosa, and the other ducklings were divided to 3 groups; first group as a control group, second group was infected (injected with $0.2 \mathrm{ml}$ of $1 \times 10^{7}$ colony-forming units/bird) without treatment and the third group was infected with $P$. aeruginosa as in second group and treated with the most effective antibiotic according to sensitivity test, Florphenicol, for 5 days, symptoms, postmortem lesions and mortalities were recorded for 4 weeks. Mortality was recorded daily, and the ducks that died were necropsied and yolk sacs and liver were cultured. After 14 days, the remaining ducks were euthanatized and necropsied. Bacterial isolates from yolk sacs and liver were identified by using the API 20 system to confirm that it was as the challenged isolated bacterial. All bacterial isolates were identified morphologically, culturally, biochemically and serologically for $P$. aeruginosa. The challenge bacterial isolates produced somewhat different and often distinctive postmortem lesion.

\section{RESULTS}

In this study, from a total of 120 samples were collected from diseased and freshly dead ducklings, 20 samples were positive for $P$. aeruginosa with percentage of $16.66 \%$

\section{Symptoms of examined duckling:}

The diseased or freshly dead ducklings showed depression, emaciation, ocular and or nasal discharges, diarrhea and sometimes enlargement of hock joint with lameness

\section{Postmortem lesions of examined duckling:}

The diseased or freshly dead ducklings showed airsacculitis, congested liver, catarrhal enteritis and sometimes presence of gelatinous material in the hock joints

Table 2: result of serotyping of isolated P.aeruginosa

\begin{tabular}{llll}
\hline Type of samples & $\begin{array}{l}\text { No. of } \\
\text { positive } \\
\text { samples }\end{array}$ & $\begin{array}{l}\text { \% of } \\
\text { positive } \\
\text { samples }\end{array}$ & $\begin{array}{c}\text { no .of isolates } \\
\text { Serotypes }\end{array}$ \\
\hline liver & 4 & 3.33 & $\begin{array}{l}\text { polyvalent I group I 3 } \\
\text { polyvalent II group J 1 }\end{array}$ \\
\hline heart & 4 & 3.33 & $\begin{array}{l}\text { polyvalent I group I 3 } \\
\text { polyvalent II group J 1 }\end{array}$ \\
\hline yolk sac & 2 & 1.66 & $\begin{array}{l}\text { polyvalent I group I 1 } \\
\text { polyvalent II group J 1 }\end{array}$ \\
\hline Cloacal swab & 7 & 5.83 & $\begin{array}{l}\text { 6 polyvalent I group I } \\
\text { polyvalent II group J 1 }\end{array}$ \\
\hline Tracheal swab & 3 & 2.50 & polyvalent I group I 3 \\
\hline total & 20 & 16.66 & $\begin{array}{c}16 \text { polyvalent I group I } \\
\text { polyvalent II group J }\end{array}$ \\
\hline
\end{tabular}

Total No. of samples were 120 for each type. 
Table 3: Susceptibility of isolated P.aeruginosa (20 isolates) to antimicrobial agents.

\begin{tabular}{ccccc}
\hline & \multicolumn{3}{c}{ (isolates) } \\
\cline { 2 - 5 } Antimicrobial agent & \multicolumn{2}{c}{ Sensitive } & \multicolumn{2}{c}{ Resistant } \\
\cline { 2 - 5 } & No. & $\%$ & No. & $\%$ \\
\hline Enrofloxacin & 10 & $50 \%$ & 10 & $50 \%$ \\
\hline norfloxacin & 9 & $45 \%$ & 11 & $55 \%$ \\
\hline Ciprofloxacin & 11 & $55 \%$ & 9 & $45 \%$ \\
\hline tylosin & 2 & $10 \%$ & 18 & $90 \%$ \\
\hline Erythromycin & 1 & $5 \%$ & 19 & $95 \%$ \\
\hline Oxytetracycline & 1 & $5 \%$ & 19 & $95 \%$ \\
\hline doxycycline & 3 & $15 \%$ & 17 & $85 \%$ \\
\hline ampicillin & 1 & $5 \%$ & 19 & $95 \%$ \\
\hline amoxicillin & 1 & $5 \%$ & 19 & $95 \%$ \\
\hline cefotaxim & 3 & $15 \%$ & 17 & $85 \%$ \\
\hline Florphenicol & 16 & $80 \%$ & 4 & $20 \%$ \\
\hline
\end{tabular}

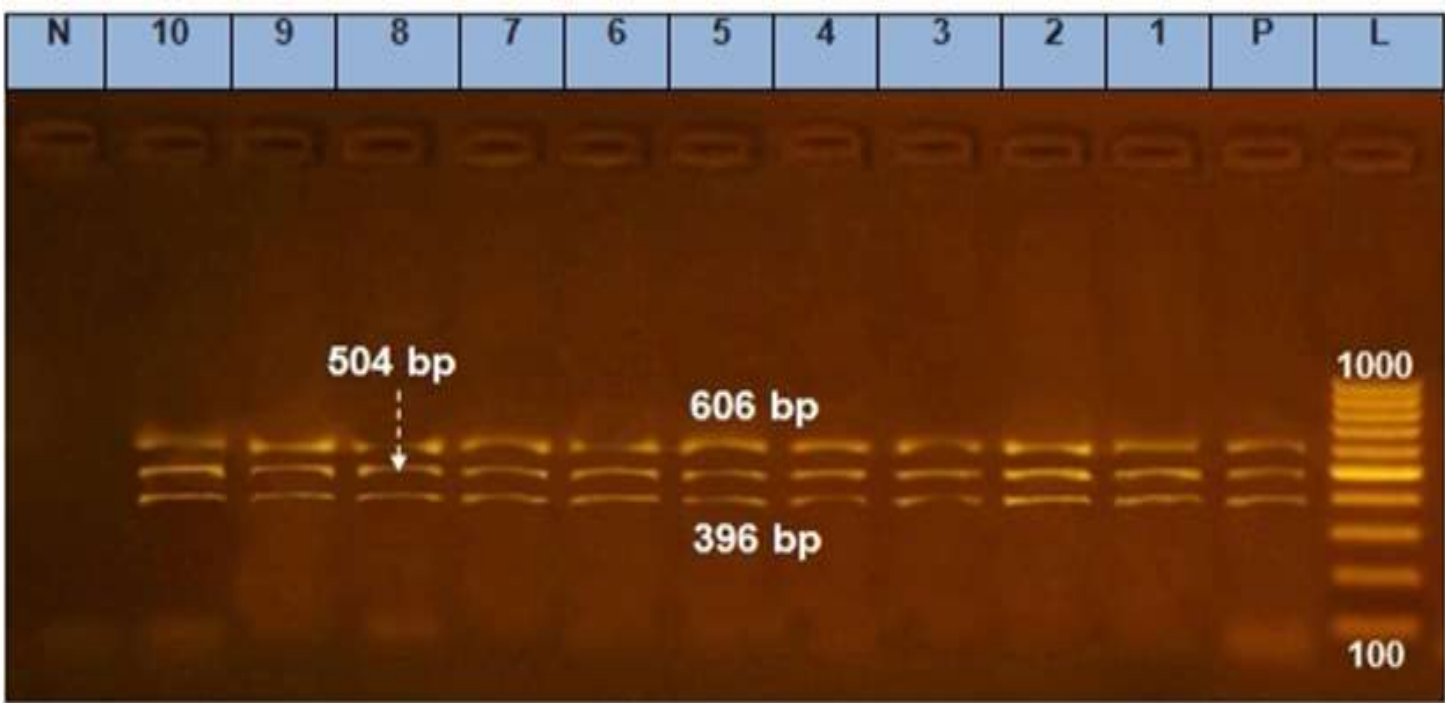

Photo (1): Agarose gel electrophoresis of multiplex PCR for virulence genes toxA (396 bp), lasI (606 bp) and oprL (504bp) $P$. aeruginosa

Photo details

Lane L: 100 bp ladder as molecular size DNA marker.

Lane P: Control positive genes.

Lane N: Control negative.

Lanes 1 to 10: Positive for 3 genes. 
Table 4: Result of multiplex PCR for virulence genes toxA (396 bp), lasI (606 bp) and oprL (504bp) P. aeruginosa

\begin{tabular}{llll}
\hline Pseudomonas sample & toxA & lasI & oprL \\
\hline 1 & + & + & + \\
\hline 2 & + & + & + \\
\hline 3 & + & + & + \\
\hline 4 & + & + & + \\
\hline 5 & + & + & + \\
\hline 6 & + & + & + \\
\hline 7 & + & + & + \\
\hline 9 & + & + & + \\
\hline 10 & + & + & + \\
\hline & + & + & + \\
\hline
\end{tabular}

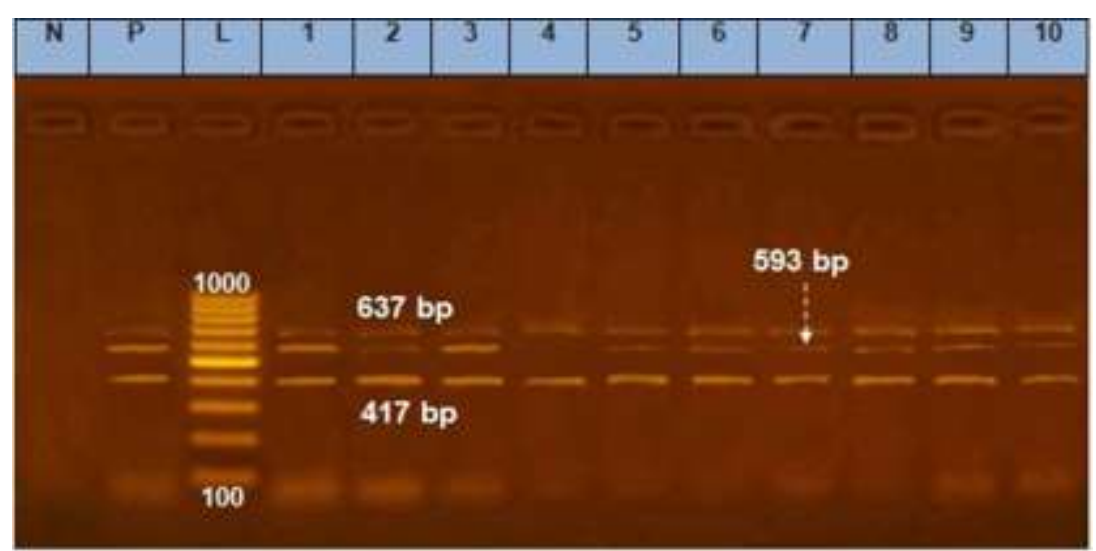

Photo 2: Agarose gel electrophoresis of multiplex PCR for AB resistance genes represented Photo details by qnrS (417 bp) blaCTX (593 bp) and mexR (637 bp) of $P$. aeruginosa.

Lane L: 100 bp ladder as molecular size DNA marker.

Lane P: Control positive genes.

Lane N: Control negative.

Lane 1 to 10: Positive for 3 genes except no 4 negative for blaCTX.

Table 5: Result of multiplex PCR for $A B$ resistance genes represented by qnrS (417 bp) blaCTX (593 bp) and mexR (637 bp) of $P$. aeruginosa.

\begin{tabular}{|c|c|c|c|}
\hline Pseudomonas sample & $q n r S$ & blaCTX & $\operatorname{mexR}$ \\
\hline 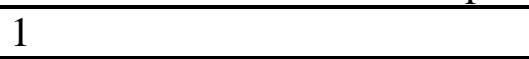 & + & + & + \\
\hline 2 & + & + & + \\
\hline 3 & + & + & + \\
\hline 4 & + & - & + \\
\hline 5 & + & + & + \\
\hline 6 & + & + & + \\
\hline 7 & + & + & + \\
\hline 8 & + & + & + \\
\hline 9 & + & + & + \\
\hline 10 & + & + & + \\
\hline
\end{tabular}


Table 6: Symptoms of Pseudomones aeruginosa challenged ducklings.

\begin{tabular}{|c|c|c|c|c|c|}
\hline Group & treatment & $\begin{array}{l}\text { general signs of illness, } \\
\text { (decreased appetite, loss of } \\
\text { weight) }\end{array}$ & $\begin{array}{l}\text { respiratory } \\
\text { distress }\end{array}$ & diarrhea & $\begin{array}{l}\text { Enlarged hock } \\
\text { joint \&lameness }\end{array}$ \\
\hline 1 & $\begin{array}{l}\text { Non } \\
\text { challenged, } \\
\text { non-treated }\end{array}$ & $\begin{array}{l}1^{\text {st }} \text { week: ---- } \\
2^{\text {nd }} \text { week : --- } \\
3^{\text {rd }} \text { week : ---- }\end{array}$ & $\begin{array}{l}1^{\text {st }} \text { week: ---- } \\
2^{\text {nd }} \text { week : --- } \\
3^{\text {rd }} \text { week : ---- }\end{array}$ & $\begin{array}{l}1^{\text {st }} \text { week: ---- } \\
2^{\text {nd }} \text { week : --- } \\
3^{\text {rd }} \text { week : ---- }\end{array}$ & $\begin{array}{l}1^{\text {st }} \text { week: ---- } \\
2^{\text {nd }} \text { week : --- } \\
3^{\text {rd }} \text { week : ---- }\end{array}$ \\
\hline 2 & $\begin{array}{l}\text { Challenged, } \\
\text { non-treated }\end{array}$ & $\begin{array}{l}1^{\text {st }} \text { week: }++ \\
2^{\text {nd }} \text { week }:+++ \\
3^{\text {rd }} \text { week }:++ \\
\end{array}$ & $\begin{array}{l}1^{\text {st }} \text { week: }++ \\
2^{\text {nd }} \text { week : }+++ \\
3^{\text {rd }} \text { week }:++ \\
\end{array}$ & $\begin{array}{l}1^{\text {st }} \text { week: }+ \\
2^{\text {nd }} \text { week }:++ \\
3^{\text {rd }} \text { week }:++\end{array}$ & $\begin{array}{l}1^{\text {st }} \text { week: }++ \\
2^{\text {nd }} \text { week : +++ } \\
3^{\text {rd }} \text { week }:+++\end{array}$ \\
\hline 3 & $\begin{array}{l}\text { Challenged, } \\
\text { treated with } \\
\text { florphenicol }\end{array}$ & $\begin{array}{l}1^{\text {st }} \text { week: }++ \\
2^{\text {nd }} \text { week : }+ \\
3^{\text {rd }} \text { week : -- }\end{array}$ & $\begin{array}{l}1^{\text {st }} \text { week: }++ \\
2^{\text {nd }} \text { week }:+ \\
3^{\text {rd }} \text { week }:+\end{array}$ & $\begin{array}{l}1^{\text {st }} \text { week: }+ \\
2^{\text {nd }} \text { week }:+ \\
3^{\text {rd }} \text { week }:+\end{array}$ & $\begin{array}{l}1^{\text {st }} \text { week: }++ \\
2^{\text {nd }} \text { week }:+ \\
3^{\text {rd }} \text { week }:+\end{array}$ \\
\hline
\end{tabular}

Table 7: Post mortem lesions in weekly sacrificed ducklings.

\begin{tabular}{|c|c|c|c|c|c|}
\hline Group & treatment & airsacculitis & $\begin{array}{l}\text { congested liver } \\
\& \text { spleen }\end{array}$ & $\begin{array}{l}\text { pericarditis, } \\
\text { perihepatitis }\end{array}$ & mortality \\
\hline 1 & $\begin{array}{l}\text { Non challenged, } \\
\text { non-treated }\end{array}$ & $\begin{array}{l}1^{\text {st }} \text { week: ---- } \\
2^{\text {nd }} \text { week :--- } \\
3^{\text {rd }} \text { week :---- }\end{array}$ & $\begin{array}{l}1^{\text {st }} \text { week: ---- } \\
2^{\text {nd }} \text { week :--- } \\
3^{\text {rd }} \text { week : ---- }\end{array}$ & $\begin{array}{l}1^{\text {st }} \text { week: ---- } \\
2^{\text {nd }} \text { week : --- } \\
3^{\text {rd }} \text { week : ---- }\end{array}$ & No \\
\hline 2 & $\begin{array}{l}\text { Challenged, non- } \\
\text { treated }\end{array}$ & $\begin{array}{l}1^{\text {st }} \text { week: }++ \\
2^{\text {nd }} \text { week }:+++ \\
3^{\text {rd }} \text { week }:++++\end{array}$ & $\begin{array}{l}1^{\text {st }} \text { week: }++ \\
2^{\text {nd }} \text { week }:+++ \\
3^{\text {rd }} \text { week }:++++\end{array}$ & $\begin{array}{l}1^{\text {st }} \text { week: }+ \\
2^{\text {nd }} \text { week }:++ \\
3^{\text {rd }} \text { week }:++++\end{array}$ & 2 \\
\hline 3 & $\begin{array}{l}\text { Challenged, treated } \\
\text { with florphenicol }\end{array}$ & $\begin{array}{l}1^{\text {st }} \text { week: }+ \\
2^{\text {nd }} \text { week }:++ \\
3^{\text {rd }} \text { week }:++\end{array}$ & $\begin{array}{l}1^{\text {st }} \text { week: }+ \\
2^{\text {nd }} \text { week }:+ \\
3^{\text {rd }} \text { week }:+\end{array}$ & $\begin{array}{l}1^{\text {st }} \text { week: }+ \\
2^{\text {nd }} \text { week }:+ \\
3^{\text {rd }} \text { week }:+\end{array}$ & No \\
\hline
\end{tabular}

Table 8: $P$. aeruginosa re-isolation rate from challenged ducklings.

\begin{tabular}{|c|c|c|c|c|c|}
\hline \multirow{2}{*}{ Group } & \multirow{2}{*}{ Treatments } & \multirow{2}{*}{$\begin{array}{l}\text { Number of } \\
\text { examined } \\
\text { ducklings }\end{array}$} & \multicolumn{3}{|c|}{ Weeks after challenged } \\
\hline & & & $1 \mathrm{st} w \mathrm{k}$ & 2 nd wk & $3 \mathrm{rd} \mathrm{wk}$ \\
\hline 1 & $\begin{array}{c}\text { Non challenged, } \\
\text { non-treated }\end{array}$ & 20 & $0 / 20(0 \%)$ & $0 / 20(0 \%)$ & $0 / 20(0 \%)$ \\
\hline 2 & $\begin{array}{l}\text { Challenged, non- } \\
\text { treated }\end{array}$ & 20 & $18 / 20(90 \%)$ & $\begin{array}{c}16 / 18 \\
(88.89 \%) \\
\end{array}$ & $\begin{array}{c}12 / 18 \\
(66.67 \%) \\
\end{array}$ \\
\hline 3 & $\begin{array}{l}\text { Challenged, } \\
\text { treated with } \\
\text { florphenicol }\end{array}$ & 20 & $10 / 20(50 \%)$ & $6 / 20(30 \%)$ & $4 / 20(20 \%)$ \\
\hline
\end{tabular}

\section{DISCUSSION}

Pseudomonas infection was considered an extensive economic problem in poultry farms, especially $P$. aeruginosa Shahat et al. (2019) which causing a high mortality in birds (Elsayed et al., 2016). The complications caused by $P$. aeruginosa in birds have appeared in the form of respiratory signs, septicemia, keratitis and sinusitis (Hai-ping, 2009).
In our study, the prevalence of Pseudomones aeruginosa was $16.66 \%$ which was higher than that recorded by Asawy and El-Latif (2010), Hamza et al. (2019) and Odoi, Hayford (2016) that was $(15.8 \%), 10 \%$ and $(9.7 \%)$ respectively. The affected ducklings showed emaciation, ocular and or nasal discharges, diarrhea and sometimes enlargement of hock joint with lameness, these symptoms nearly similar to that recorded by (Qureshi et al., 2010). 
Virulent isolates of this bacteria cause dehydration, diarrhea, septicemia, dyspnea, and death as reported by (Harbottle et al., 2007) Regarding to lesions showed on freshly dead ducklings were airsacculitis, congested liver, catarrhal enteritis and sometimes presence of gelatinous material in the hock joints $P$. aeruginosa causes sinusitis, respiratory infection, keratoconjuctivitis, keratitis and septicemia and responsible for septicemia, pyogenic infections, endocarditis and lameness De Vos et al. (2009). Infections may also occur through contaminated vaccines, skin wounds and antibiotic solutions or syringe used for injection and it may be systemic affecting tissues, multiple organs or localized in air sacs or infraorbital sinus producing swelling of the wattles, head, sinuses and joints in affected birds. $P$. aeruginosa were isolated from birds and poultry farms all over the worled Sams (2001). P.aeruginosa is gram-negative, motile, non-spore forming rods (Elsayed $e t$ $a l ., 2016)$. It is characterized by producing of watery soluble green pigment with a specific fruity odor. (Barnes, 2003) reported that $P$. aeruginosa produces cheesy deposits and dyspnea. Congestion of internal organs, peri-hepatitis and pericarditis were reported by (Kheir El din and Awaad 1986). The identification of these strains should be considered during microbiological examination. In this study, identification showed typical colorless colonies on MacConkey agar media and green-blue color colonies for Pseudomonas spp. on Pseudomonas agar media similar to Haleem et al. (2011), also the morphological features with gram stain showed a gram-negative rods of pseudomonas spp. these findings were supported by Tripathi et al. (2011).

The of bacteriological examination for samples showed a green-blue color colonies with an odor like sweet grape were clear on Pseudomonas agar and didn't ferment lactose sugar in MacConkey agar. Different biochemical tests were used to identify $p$. aeruginosa which showed a clear positive result for catalase test, oxidase test, Citrate reaction, arginine hydrolysis (gives brown color) and gelatin liquefaction but is negative to indole production, methyl red reaction and Voges Proskauer test. $P$. aeruginosa produces pyocyanin and pyoverdin pigments, grows well at $42^{\circ} \mathrm{C}$ and $4^{\circ} \mathrm{C}$ and gives red butt and slant without $\mathrm{H} 2 \mathrm{~S}$ production on triple sugar iron agar. But the biochemical scheme cannot separate other species due to the high resemblance among the results of isolates so further identification was done by serological test and PCR to reach to accurate species.

Result of serological identification of suspected isolates of $P$. aeruginosa were explained in table (2) showed that serologically identified isolates into 16 isolates of polyvalent I group I and 4 isolates of polyvalent II group J

The highest rate of isolation was from cloacal swabs, so fecal matter considered as the most dangerous source for spreading of $P$. aeruginosa inside ducks farms, then the second rate of isolation was from heart and liver and these indicate the ability of $P$. aeruginosa to cause septicemia, respiratory infections, septicemia and mortalities and these agree whith (Eman et al., 2017), and the last rate of isolation was from yolk sac and this indicate that $P$. aeruginosa can be transmitted vertically from diseased dam.

P. aeruginosa was listed as the head of most three frequent Gram-negative pathogens and is linked to the worst visual diseases. Its outbreak varies from 2 to 100\% (Saad et al., 2017). Serotypes O10 H, O6 G, O11 E, and O2 G E of P. aeruginosa were detected by Shahat et al. (2019).

In table (3): The interpretation of antimicrobial resistance of $P$. aeruginosa isolates according to CLSI (2018).

Susceptibility of $P$. aeruginosa for different antimicrobials demonstrated that an obvious resistance was noted against 
Erythromycin, Oxytetracycline, Ampicillin and Amoxicillin (95\%) and was followed by Tylosin (90\%) and Doxycycline and Cefotaxim (85\%) and the highest sensitivity was observed against Florphenicol (80\%), Ciprofloxacin (55\%), Enrofloxacin (50\%) and Norfloxacin (45\%), so the most influential antibiotics was Florphenicol $(80 \%)$ and it used for treatment in experimental design. Shahat et al. (2019) recorded that antimicrobial resistance is important problems confronting the world and it is elevating in developing countries. Therefore, it's important to detect $P$. aeruginosa quickly and identify its susceptibility pattern; this may avoid useless antibiotic treatment which presents antibiotic-resistant pathogens (Hamisi et al., 2012). The antimicrobial susceptibility reported that the identification of $P$. aeruginosa with traditional methods takes a long time to perform. Shahat et al. (2019) detect that Antimicrobial agents Resistance P.aeruginosa isolates where Intermediate Sensitive to Sulphamethazole, Gentamycin, Erythromycin, Tetracycline, Ciprofloxacin, Amoxicillin, Ampicillin, Streptomycin, Nalidixic acid, Norfloxacin. Atlas and Synder (2006). Reported that antibiotic sensitivity tests for all isolates were resist to ceftiofur, sulfisoxazole, lincomycin, bacitracin, oxytetracycline, penicillin, naladixic acid, erythromycin, and tetracycline, varied to other antibiotics, sensitive to gentamicin. The isolates were identified by biochemical tests as urease production test, motility test, catalase test, oxidase test, citrate utilization test, triple sugar iron agar test, indole test, nitrate reduction test, gelatinase liquefaction, oxidative-fermentative test, haemolysin production, alkaline protease production, lecithinase production and Sugar Fermentation. In Ghana a study carried out show that $P$. aeruginosa all isolated from poultry were susceptible to antibiotic levofloxacin from 20 to $100 \%$ and $75 \%$ were intermediate susceptibility to aztreonam. and resistance to carbapenems, cephalosporins, penicillins, monobactam, quinolones and aminoglycoside and $\beta$ -
Lactamase encoding genes as (blaIMP, blaVIM) not detected in any isolates and the class 1 integron carry resistant genes detected in $89.4 \%$ of the multi-drug resistant strains Odoi (2016) Identified blaVIM gene in $P$. aeruginosa from poultry resembled corresponding regions in its clinical isolates of $P$. aeruginosa and these isolates were resistant to all $\beta$-lactam tested, as, imipenem, meropenem, aztreonam, and ceftazidime Bassetti et al. (2013) and Zhang et al. (2017). In Nigeria $P$. aeruginosa was resist to tobramycin, $\beta$ lactams, nitrofurantoin, tetracycline and sulfamethoxazole-trimethoprim, while ofloxacin, ertapenem and imipenem were effective against the bacterial pathogens Aniokette et al. (2016). In Pakistan, a study investigated the causative bacteria for necropsy in chicken, about $28 \%$ prevalence were P. aeruginosaand it was $100 \%$ resistant towards meropenem, colistin, erythromycin, ciprofloxacin and ceftriaxone, while $60 \%$ was sensitivit against ampicillin, cefoperazone, ceftazidime, sulbactam and rifampicin. Isolates were multidrug resistance to other antibiotics Sharma et al. (2017). Ahmed (2016) and Tartor and Elnaenaeey (2016) who mentioned that $P$. aeruginosa was highly resistance to Tetracycline, Erythromycin and Ampicillin, Sulphamethazone, Erythromycin, Ampicillin, Tetracycline, Amoxicillin and Erythromycin followed by Nalidixic acid (57.1\%), Streptomycin (42.9\%). Abd ElGawad et al. (1998) reported that P. aeruginosa isolates of chickens were sensitive to Tetracycline. Abdel-Tawab et al. (2016) found that P.aeruginosa isolates were resistant to Nalidixic acid (80\%). Mohammad (2013) recorded a high sensitivity with Ciprofloxacin and Norfloxacin but low sensitivity of P. aeruginosa to Ciprofloxacin and Norfloxacin was recorded by Abd ElTawabet et al. (2014). Abd El-Gawad et al. (1998) and Kurkure et al. (2001) reported a high sensitivity to antibiotic Gentamycin (88.6\% and $100 \%$ respectively). These variations among the results may be 
attributable to the difference in many conditions surrounding hatcheries or may be a result of hyper-mutation which occurred frequently in P.aeruginosa strains and leading to the development of various antimicrobial resistance as reported by Zheng et al. (2019). Antibiotic-resistant bacteria (ARB) can easily spread alongside the food chain and cause most of public health hazards (Da Costa et al., 2013, FAO, 2015 and WHO, 2015).

PCR method has been used to provide a specific, rapid, simple, and vastly identifiction of $P$. aeruginosa which has got an enormous numbers of some extracellular virulence factors and cellular components which implicated in pathogenesis Qin et al. (2003) and (Habeeb et al., 2012). Molecular examination of $P$. aeruginosa serologically identified ten isolates in this study for detection of virulence genes toxA gene, lasI gene and oprL gene of $P$. aeruginosa using multiplex PCR.

In photo No (1) and table No (4) Result of multiplex PCR for virulence genes represented by toxA gene at $396 \mathrm{bp}$, lasI gene at $606 \mathrm{bp}$ and oprL gene at 504bp of $P$. aeruginosa show that all isolates where positive for the 3 examined virulence genes and these indicate that all isoletes were highly virulent strains. $P$. aeruginosa has virulence repertoire such as lipopolysaccharide, elastase, alkaline proteases, pyocyanin, pyoverdin, hemolysins, phospholipase $\mathrm{C}$ and rhamnolipids. Some factors are coordinated by a global regulatory system activated by autoinducers involved (lasI) gene (Habeeb et al., 2012). Also some genes as exoS, exoT, exoU, and exoY genes which regulate the action of $P$. aeruginosa secretion system which injects toxic effectors proteins into the cytosol of host cells and accompanied by inferior clinical outcomes and elevated mortality rates (Hauser, 2009). P. aeruginosa uses the virulence factor exotoxin A to inactivate eukaryotic elongation factor 2 in the cell, such as the diphtheria toxin does, hence eukaryotes can't synthesize protein and necrotize (Eman et al., 2017). The powerful toxins of bacteria released during bacteremia continu after $P$. aeruginosa killed by antimicrobial (Kirienko et al., 2015). The main troublesome characters of $P$. aeruginosa is a minimal susceptibility to many types of antibiotics, making it a very hard bacteria to be eliminated and this due to $P$. aeruginosa genome contains the largest known resistance island genes (Khattab et al., 2015). The important reason for antimicrobial resistance was impermeability which belongs to the outer membrane lipoprotein (oprL gene) that implicated in efflux transport systems and its effects on cell permeability (De Vos et al., 1997). Antibiotics are profusely administered for therapeutic and prophylaxis purposes in veterinary field (Dandachi et al., 2018).

Concerning the results of virulence factors we found that the detection of oprL gene in all isolates $(100 \%)$ confirmed the existence of $P$ aeruginosa DNA which considerd a specific marker for molecular detection of P.aeruginosa and encodes a protein in the inner and outer membranes, which is essential for the invasion of epithelial cells (De Vos et al., 1997 and Shahat et al., 2019), the same result obtained by Hassan (2013) and in efflux transport systems affecting cell permeability so there is a strong relation between detection of oprL and phenotypic antibiotic resistance that reported by Qin et al. (2003) and Lavenir et $a l .$, (2007). In this study, the incidence rate of toxA gene was $71.42 \%$, as shown in similar results of toxA reported by Qin et al. (2003) and Lavenir et al. (2007). Khan and Cerniglia (1994) showed that $96 \%$ of tested P.aeruginosa isolates contained a toxA gene. Furthermore, the exoS and lasB genes were detected in five isolates of P.aeruginosa ( $71.42 \%$ for each of them) and this percentage was nearly similar to Tartor and El-naenaeey (2016) who found that the colossal majority of $P$. aeruginosa isolates showed exoS gene $(78.6 \%)$. The higher percentage was recorded by Nikbin et al. 
(2012) who detected lasB in all strains of P.aeruginosa (100\%). The mentioned virulence genes in this work such as, toxA, exoS and lasB were coordinated by a critical global regulatory systems consisted of transcriptional activator protein (LasR) and Pseudomonas autoinducer, (PAI), the central gene responsible for activation of this system was putative autoinducer synthase (lasI) (Habeeb et al., 2012). The lasI gene which is a quorum sensing Regulation gene was detected. Venturi (2006) reported that the lasI is not detected in any Pseudomonas spp. otherwise $P$. aeruginosa strain. Percentage of lasI gene was less than that was detected by Alshalah et al. (2017) who succeeded in the amplification of lasI gene in all clinical isolates of P.aeruginosa. In addition to, Nikbin et al. (2012) whom explained that the possession of $P$. aeruginosa for several virulence genes make it a reason for various levels of virulence and pathogenicity.

In photo No (2) and table No (5) Result of multiplex PCR for $\mathrm{AB}$ resistance genes represented by qnrS gene at $417 \mathrm{bp}$, blaCTX gene at $593 \mathrm{bp}$ and mexR gene at 637 bp of $P$. aeruginosa show that all isolates where positive for the 3 examined $\mathrm{AB}$ resistance except isolate No 4 were negative for blaCTX and these indicate that all isolates were highly $\mathrm{AB}$ resistance exept isolate No 4 was not have blaCTX resistance gene and this results differ with Shahat et al. (2019) which detect virulence and disinfectant resistance genes in P.aeruginosa isolates such as (oprL, toxA, exoS, lasB and lasI) which result in amplicons 504bp, 396bp, 118bp, 1220bp and 606bp respectively, and cleared that oprL gene was disclosed in all $P$. aeruginosa isolates with percentage of $100 \%$, while other genes were detected with the same percentage $71.4 \%$, which it was Serotypes of $\mathrm{P}$. aeruginosa Group P. aeruginosa $\mathrm{O} 10 \mathrm{H} P$. aeruginosa $\mathrm{O} 6 \mathrm{G} \mathrm{P}$. aeruginosa $\mathrm{O} 11 \mathrm{E} \mathrm{P}$. aeruginosa $\mathrm{O} 2 \mathrm{G}$ and found also resistant genes in P.aeruginosa isolates (no.7 isolates) OprL gene 7 (100\%)
toxA gene 5 (71.42\%) lasI gene $5(71.42 \%)$ lasB gene $5(71.42 \%)$ exoS gene 5 (71.42\%) qacA/B gene $1(14.28 \%)$ qacC/D gene $1(14.28 \%)$ qacED1 gene 7 (100\%).

Regarding the results of our study in tables $(6,7)$, The infected ducklings showed general signs of illness (decreased appetite and loss of body weight), respiratory distress, diarrhea and sometimes enlargement of hock joint with lameness, the severity of symptoms appeared in the $2^{\text {nd }}$ challenged groups in the first week and began to decline after treatment with florphenicol in the $3^{\text {rd }}$ group from the $2^{\text {nd }}$ week without mortalities, however these symptoms continued in the non- treated group till the3rd week with mortality $10 \%$ which had lesions of air-sacculitis, congested liver, congested spleen, pericarditis and peri-hepatitis.

In table (8) re-isolation rate of $P$. aeruginosa from challenged ducklings was negative in group1 and gradually decreased in group 2 due to normal immunity and also decreased in group 3 but it more decreased than group 2 due to use of effective antibiotic in treatment in the third group, so use of effective antibiotic after sensitivity test was important for rapid cure of diseased ducks and effectively decrease rate of shedding of $P$. aeruginosa to surrounding environment and control disease. The prevalence of $P$. aeruginosa was $16.66 \%$ which was higher than that recorded by Asawy and El-Latif (2010), Hamza et al. 2019 and Odoi (2016) that was $(15.8 \%), 10 \%$ and $(9.7 \%)$ respectively. The affected ducklings showed emaciation, ocular and or nasal discharges, diarrhea and sometimes enlargement of hock joint with lameness, these symptoms nearly similar to that recorded by (Qureshi et al., 2010). The lesions showed on freshly dead ducklings were air-sacculitis, congested liver, catarrhal enteritis and sometimes presence of gelatinous material in the hock joints. 


\section{CONCLUSION}

Our study proved that virulence genes owned by the $P$. aeruginosa confirming its pathogenicity for ducks, especially in the presence of oprL gene which plays a great role in antimicrobial resistance, so biosafety was recommended for hatcheries and farms, hygiene, cleaning and disinfection will reduce $P$. aeruginosa spreading in the farms.

\section{REFERENCES}

Abd El-Gawad, AM.; Ali, SM. and Azzaz, HA. (1998): Some studies on pseudomonas aeruginosa infection in Shahat et al., 2019 SVU-IJVS, 2 (2): 52-70 64 growing chickens in Assuit farm. Assiut Veterinary Medical Journal, 38: 90-97

Abd El-Tawab, AA.; Fatma, IE.; Dalia, FK. and Mo'men, MA. (2014): PCR detection and gene sequence of Pseudomonas aeruginosa isolated from broiler chickens. Benha Veterinary Medical Journal, 27(2):449-455

Abdel-Tawab, AA.; Nasef, AS. and Ibrahim, AO. (2016): Bacteriological and Molecular Studies on Bacteria Causing Omphalitis in Chicks with Regard to Disinfectant Resistance. Global Veterinaria, 17 (6): 539-545.

Ahmed, I. (2016): Studies on omphalitis in baby chicks. Thesis, Master of Veterinary Medicine, University of Beni-Suif.

Alshalah, AJZ.; Al-Daraghi, AW. and Khaleel, IA. (2017): Rapid Detection For lasI and lasR Genes of Pseudomonas Aeruginosa at Deference Iraqi Hospitals by Polymerase Chain Reaction (PCR) Technique. International Journal of Chem Tech Research,10 (1): 409-414.

Aniokette, U.; Iroha, CS.; Ajah, MI. and Nwakaeze, AE. (2016): Occurrence of multi-drug resistant Gram-negative bacteria from poultry and poultry products sold in Abakaliki. Journal of Agricultural Science and Food Technology. 2:119-124

Archambault, M.; Petrov, P.; Hendriksen, R.S.; Asseva, G.; Bangtrakulnonth, A.; Hasman, H. and Aarestrup, F.M. (2006): Molecular characterization and occurrence of extended-spectrum beta-lactamase resistance genes among Salmonella enterica serovar Corvallis from Thailand, Bulgaria, and Denmark. Microb Drug Resist. Fall; 12(3):192-8.

Asawy, A.M.E. and El-Latif, M.M.A. (2010): Some bacteriological and serological studies on enteritis in ducks. Assiut Veterinary Medical Journal 2010 Vol.56 No.125 pp.239249.

Atlas, R.M. and Snyder, J.W. (2006): "Handbook of Media for Clinical Microbiology". New York: 2nd Ed., CRC Publisher, 278-339.

Bapat, D.A.; Krtlkarrri, V.B. and Ninrje, D.V. (1985): Mortality in chicks due to $\mathrm{P}$. aeruginosa. Indian $\mathrm{J}$. of Animal Science. 55(7): 538 - 539.

Barnes, HJ. (2003): Miscellaneous Bacterial Diseases, Diseases of Poultry. 11th ed. pp. 852-854, Iowa State University Press, Ames.

Bassetti, M.; Merelli, M.; Temperoni, C. and Astilean, A. (2013): New antibiotics for bad bugs Annual Clinical Microbiology and Antimicrobials.

Cheesbrough, M. (2000): Pseudomonas and related organisms. Biochemical test to identify bacteria. Antibiotic susceptibility testing. In: District Laboratory Practice in tropical countries. Cambridge University Press, New York, USA, pp. 19331943.

CLSI (2018): Performance Standards for Antimicrobial Disk Susceptibility Testing. 28th ed. CLSI standard M100. Clinical and Laboratory Standards Institute.

Da Costa, PM.; Loureiro, L. and Matos, AJF. (2013): Transfer of multi- drug 
resistant bacteria between intermingled ecological niches: the interface between humans, animals and the environment. International Journal of Environmental Research and Public Health, 10: 278-294.

Dandachi, I.; Sokhn, ES.; Dahdouh, EA.; Azar, E.; El-Bazzal, B.; Rolain, J-M. and Daoud, Z. (2018): Prevalence and Characterization of MultiDrugResistant Gram-Negative Bacilli Isolated From Lebanese Poultry: A Nationwide Study. Frontiers in Microbiology, 9: 550.

Davies, J. and Davies, D. (2010): Origins and Evolution of Antibiotic Resistance. Microbiology and Molecular Biology Reviews, 74 (3): 417-433.

De Vos, P.; Garrity, GM.; Jones, D.; Krieg, NR.; Ludwig, W.; Rainey, FA.; Schleifer, KH.; Whitman, WB. and Bergey's (2009): Manual of Systematic Bacteriology. New York: Springer: p. 1450.

De Vos, D.; Lim, AJ.; Pirnay, JP.; Struelens, M.; Vandenvelde, $C$.; Duinslaeger, L.; Vanderkelen, A. and Cornelis, P. (1997): Direct detection and identification of Pseudomonas aeruginosa in clinical samples such as skin biopsy specimens and expectorations by multiplex PCR based on two outer membrane lipoprotein genes, oprI and oprL. The Journal of Clinical Microbiology, 35: 1295-1299.

Elsayed, MSA.; Ammar, AM.; Al Shehri, ZS. and Abd-El Rahman, NA. (2016): Virulence Repertoire of Pseudomonas aeruginosa from some Poultry Farms with Detection of Resistance to Various Antimicrobials and Plant Extracts. Cellular and Molecular Biology, 62: 124-132.

Eman, MF.; Heba, R.; Bakheet, AA.; Abd ElHafez, SA. and Heba, B. (2017): Advanced studies on Pseudomonas aeruginosa infection in chicken. Animal Health Research Journal, 5(4): 207-217.
FAO (2015): Status Report on Antimicrobial Resistance. Rome: Food and Agriculture Organization of the United Nations.

Finegold, SM. and Martin, WG. (1982): Bailey and Scott's Diagnostic Microbiology, (Ed.6) the C.V. Mosby Company. St. Louis, Toronto, London.

Garcia, L.S. and Isenberg, H.D. (2007): "Aerobic bacteriology: Clinical Microbiology Procedures Handbook". Washington, D.C.: 2nd Ed., Vol. 3.0.1. ASM Press.

Glupczynski, Y.; Bogaerts1, P.; Deplano, A.; Berhin, C.; Huang, C.; Van, J. and Villalobos, H. (2010): Detection and characterization of class A extendedspectrum b-lactamaseproducing Pseudomonas aeruginosa isolates in Belgian hospitals. Journal of antimicrobial agents and Chemotherapy, 65: 866-871.

Habeeb, RH.; Saad, SN. and Al-Jubory, A. (2012): A study of efficacy of disinfectants and bacterial contamination in Alhilla teaching hospital. Medical journal of Babylon, 9(4):890-900.

Hai-ping, HE. (2009): Isolation and identify of Pseudomonas aeruginosa in chicken dead-embryos Chinese Qinghai. Journal of animal veterinary sciences, 3: 25-27.

Haleem, H.; Kadhim, J.; Ilham, T. and Banyan, A. (2011): Isolation of Pseudomonas aeruginosa from Clinical Cases and Environmental Samples, and Analysis of its Antibiotic Resistant Spectrum at Hilla Teaching Hospital. Medical Journal of Babylon, 8: 618-624.

Hamisi, Z.; Tuntufye, H. and Shahada, F. (2012): Antimicrobial resistance phenotypes of Escherichia coli isolated from tropical free-range chickens. International Journal of Science and Research, 3(9): 34.

Hamza, M. Eid; Abdelazeem M. Algammal; Wael K. Elfeil; Fatma M. Youssef; Sawsan M. Harb and Ehab M. Abd- 
Allah (2019): Prevalence, molecular typing, and antimicrobial resistance of bacterial pathogens isolated from ducks, Veterinary World, EISSN: 2231-0916.

Harbottle, H.; Thakur, S.; Zhao, S.; White, D.G. and Taylor, P. (2007): Genetics of Antimicrobial Resistance. Animal Biotechnology, 37-41.

Hassan, H.M. (2013): Characterization of Pseudomonas aeruginosa isolated from different pathological lesions in chickens. M. V. Sc. Thesis, faculty of veterinary medicine, University of Benisuef.

Hauser A.R. (2009): The type III secretion system of Pseudomonas aeruginosa: infection by injection. Nature Reviews Microbiolo gy. 7: 654-665.

Javiya, V.A.; Ghatak, S.B.; Patel, K.R. and Patel, J.A. (2008): Antibiotic susceptibility patterns of Pseudomonas aeruginosa at a tertiary care hospital in Gujarat, India. Indian J Pharmacol. Oct; 40(5): 230234.

Kheir El-Din, A.W. and Awaad, M.H.H. (1986): Pseudomonas infection in turkeys. Vet. Med. J., 33 (2), 211218.

Khan, A.A. and Cerniglia, C.E. (1994): Detection of Pseudomonas aeruginosa from clinical and environmental samples by amplification of the exotoxin A gene using PCR. Applied and Environmental Microbiology, 60: 3739-3745.

Khattab, M.A.; Nour, M.S. and ElSheshtawy, NM. (2015): Genetic identification of Pseudomonas aeruginosa virulence genes among different isolates. Journal of Microbial and Biochemical. Technology, 7: 274- 277.

Kirienko, N.V.; Ausubel, F.M. and Ruvkun, G. (2015): Mitophagy confers resistance to siderophore-mediated killing by Pseudomonas aeruginosa. The National Academy of Sciences of the United States of America, 112 (6): 1821-1826.
Kurkure, N.V.; Kalorey, $\quad$ D.R.; Shubhangiwarke, P.S. and Bhandarkar, AG. (2001): Mortality in young broilers due to pseudomonas aeruginosa. Indian Journal of Veterinary Research. 10: 55-57.

Lavenir, R.; Jocktane, D.; Laurent, F.; Nazaret, $S$. and Cournoyer, $B$. (2007): Improved reliability of Pseudomons aeruginosa PCR detection by the use of the specific ecfx gene target. Journal of Microbiology, 70: 20-29.

Legakis, N.; Majtan, $V$. and Wang, S. (1982): Serotypes of Pseudomonas aeruginosa in clinical specimens in relation to antibiotic susceptibility. Journal of Clinical. Microbiology, 16 (3): 458-463.

Middleton, J.R.; Fales, W.H.; Luby, C.D.; Landsay Oaks, J.; Sanchez, S.; Kinyon, J.M.; Wu, C.C.; Maddox, C.W. and Hartmann, F. (2005): Surveillance of Staphylococcus aureus in veterinary teaching hospitals. Journal of Clinical Microbiology, 43(6): 2916-2919.

Mena, K.D. and Gerba, C.P. (2009): "Risk Assessment of Pseudomonas aeruginosa in Water". Reviews of Environmental Contamination and Toxicology, 201, 71-115.

Mohammad, H.H. (2013): Phenotypic Investigation for Virulence factors of Pyocine producing Pseudomonas aeruginosa isolated from Burn Wounds, Iraq. International Journal of Scientific \& Engineering Research, 4(7): 2114-21.

Nikbin, V.S.; Aslani, M.M.; Sharafi, Z.; Hashemipour, M.; Shahcheraghi, F. and Ebrahimipour, G.H. (2012): Molecular identification and detection of virulence genes among Pseudomonas aeruginosa isolated from different infectious origins. Iranian Journal of Microbiology, 4(3): 118- 123.

Odoi Hayford (2016): Isolation and characterization of multi-drug resistant pseudomonas aeruginosa 
from clinical, environmental and poultry litter sources in Ashanti Region of Ghana. Thesis for the degree of Master of Philosophy at the Kwame Nkrumah University of Science and Technology, KumasiGhana.

Qin, X.; Emerson, J.; Stapp, J.; Stapp, L.; Abe, P. and Burns, L. (2003): Use of real-time PCR with multiple targets to identify Pseudomonas aeruginosa and other non-fermenting gram-negative bacilli from patients with cystic fibrosis. Journal of clinical Microbiology, 4: 4312-4317.

Quinn, P.J.; Markey, B.K.; Carter, M.E.; Donnelly, W.J. and Leonard, F. (2002): Veterinary Microbiology and Shahat et al., 2019 SVU-IJVS, 2 (2): 52-70 69 Microbial Disease.Iowa State University Press, Ames, and USA.pp.124- 126.

Qureshi, S.D.; Wani, S.A.; Hussain, I.; Banday, M.T.; Mir, I.A.; Farooq S. and Bhat, M.A. (2010): Isolation and molecular characterization of avian pathogenic Escherichia coli and Pseudomonas aeruginosa from mortality in ducks in Kashmir, India, Indian Journal of Animal Sciences 80 (3): 225-228.

Robicsek, A.; Strahilevitz, J.; Sahm, D.F.; Jacoby, G.A. and Hooper, D.C. (2006): Qnr prevalence in ceftazidime-resistant

Enterobacteriaceae isolates fromthe United States. Antimicrob Agents Chemot her 50:2872-2874.

Saad, Z.A.; Soad, A.N.; Mahmoud, E.; Rehab, E. and Nashwa, E. (2017): Resistance patterns associated with bacterial pathogens causing omphalitis in baby chicks, journal of Bioscience Research. 14(4): 845-851.

Saif, Y.M.; Barnes, H.J.; Glisson, J.R.; Fadly, A.M. and McDougald, L.R. (2008): Poultry Disease. Iowa State University Press, Ames, USA.

Shahat S. Hala; Hams M.A. Mohamed; Mohammed W. Abd Al-Azeem; Soad A. and Nasef (2019): Molecular
Detection of Some Virulence Genes in Pseudomonas aeruginosa isolated from Chicken Embryos and Broilers. SVU- International Journal of Veterinary Sciences, 2 (2): 52-70.

Sams, AR. (2001): Poultry Meat Processing. Boca Raton: CRC Press; p. 345.

Sánchez, P.; Linares, J.F.; Ruiz-Díez, B.; Campanario, S.; Navas, A.; Baquero, F. and Martínez, J.L. (2002): Fitness of in vitro selected Pseudomonas aeruginosa nalB and $n f x B$ multidrug resistant mutants. Journal of Antimicrobial Chemotherapy (2002) 50, 657-664.

Schmidt, H.; Knop, C.; Aleksic, S.; Heasemann, J. and Krach, H. (1995): Development of PCR for Screening of entero-aggregative Escherichia coli. J. clin. Microbiol, 33(3):701705.

Sharma, S.; Galav, V.; Agrawal, M.; Faridi, F. and Kumar, B. (2017): Multi-drug resistance pattern of bacterial flora obtained from necropsy samples of poultry. Journal of Animal Health and Production. 5:165-171.

Shukla, S. and Mishra, P. (2015): Pseudomonas aeruginosa infection in Broiler Chicks in Jabalpur, international journal of extensive Research, 6: 37-39.

Silby, M.W.; Winstanley, C.S.; Godfrey, A.C.; Levy, S.B. and Jackson, R.W. (2011): "Pseudomonas genomes: diverse and adaptable". FEMS Microbiol. Rev., 35, 652-680.

Tartor, Y.H. and El-naenaeey, E.Y. (2016): RTPCR detection of exotoxin genes expression in multidrug resistant Pseudomonas aeruginosa. Cellular and molecular biology, 62 (1): 56-62.

Tripathi, P.; Banerjee, G.; Saxena, S.; Gupta, SM. and Ramteke, P.W. (2011): Antibiotic resistance pattern of Pseudomonas aeruginosa isolated from patients of lower respiratory. The Journal of Veterinary Advance, 3(7): 180-185 
Venturi, V. (2006): Regulation of quorum sensing in Pseudomonas. FEMS, Microbiology Reviews, 30: 274-291.

Walker, S.E.; Sander, J.E.; Cline, J.L. and Helton, J.S. (2002): Characterization of Pseudomonas aeruginosa, Avian Dis.; 46(4):1045-50.

WHO (2015): Global Action Plan on Antimicrobial Resistance. Geneva: World Health Organization.

Xu, J.; Moore, JE; Murphy, PG.; Millar, BC. and Elborn, JS. (2004): Early detection of Pseudomonas aeruginosa - comparison of conventional versus molecular (PCR) detection directly from adult patients with cystic fibrosis (CF). Annals of
Clinical Microbiology and Antimicrobials 2004, 3:21.

Zhang, R.; Liu, Z.; Li, J.; Lei, L.; Yin, W.; Li, M.; Wu, C.; Walsh, T.R.; Wang, Y.; Wang, S. and Wua, Y. (2017): Presence of VIM-positive Pseudomonas species in chickens and their surrounding environment. Antimicrobial Agents and Chemotherapy. 61:1-5.

Zheng Pang; Renee Raudonis; Bernard R. Glick; Tong-Jun Lin and Zhenyu Cheng (2019): Antibiotic resistance in Pseudomonas aeruginosa: mechanisms and alternative therapeutic strategies. Biotechnology Advances journal 37, 177-192.

\section{الضراوة لبكتريا السودوموناس ايرجينوزا المعزولة من البط الصغير ومقاومته للمضادات الحيوية مع محاوله تجريبيه للعلاج الطن}

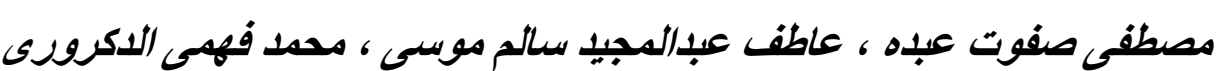

E-mail: dr.mostafaabdou@yahoo.com Assiut University web-site: www.aun.edu.eg

أجريت الدر اسة الحالية في محافظة كفر الثيخ لعزل ميكروب السيدوموناس ايروجوناز المن • ب ا بطه من الأعضاء الداخلية لصغار

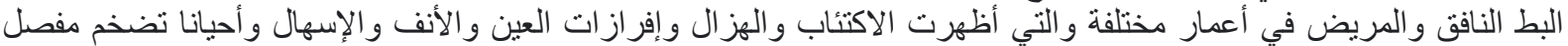

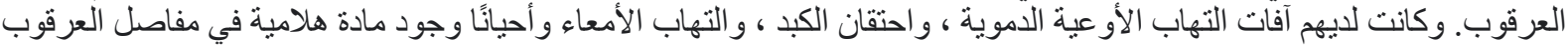

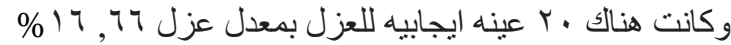

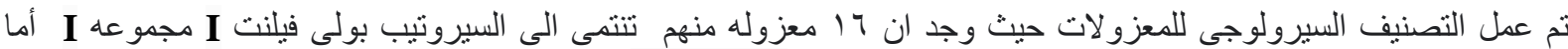

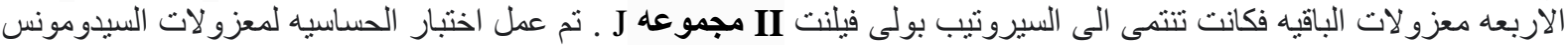

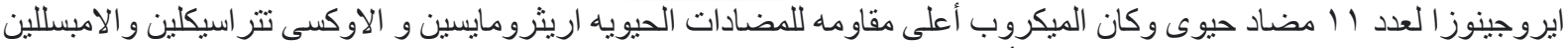

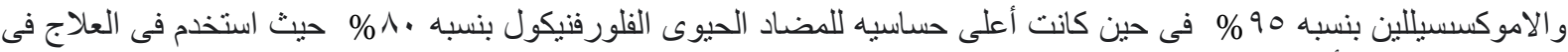
العدوى التجريبيه و أعطى نتائج جيده .

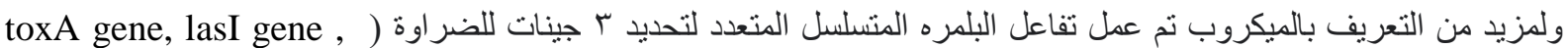

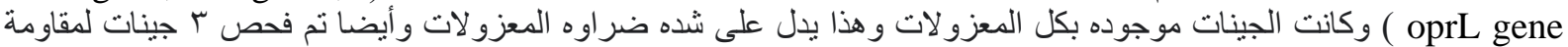

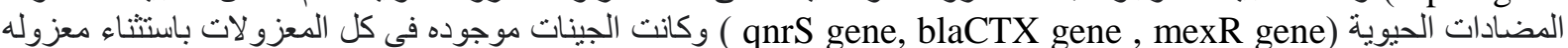

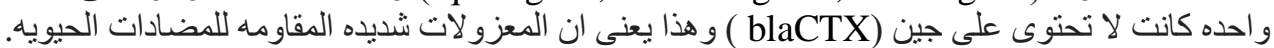

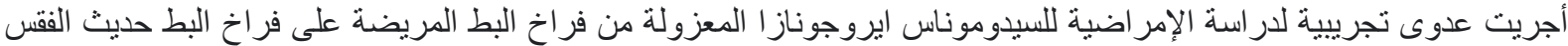

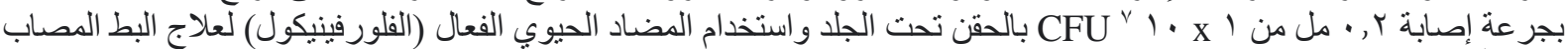

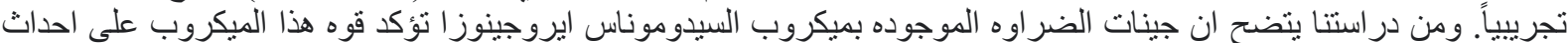

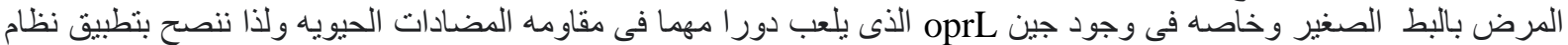

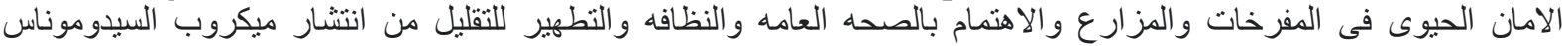

